\title{
THE APPLICATION OF SIMPLICITY CONCEPT OF TAXATION ON FINAL INCOME TAX REGIME IN INDONESIA*
}

\author{
Adrianto Dwi Nugroho** \\ Department of Tax Law, Faculty of Law Universitas Gadjah Mada, Yogyakarta \\ Jalan Sosio Yustisia No. 1 Bulaksumur, Sleman, D.I. Yogyakarta 55281
}

\begin{abstract}
The Final Withholding Tax (hereinafter, FWHT) requires certain taxable income to be taxed in accordance with special rules that differ from the calculation of income taxes in general, and thus, disregarding the payer's ability to pay. One concept upheld in justifying FWHT is simplicity. However, the concept has not been defined clearly in FWHT regime in Indonesia. The study shows that conceptually, there are two definitions of simplicity in understanding its manifestation in FWHT regime in Indonesia. However, these definitions have deviated from the Pay As You Earn (PAYE) concept, which provides basis for any withholding system in taxation.
\end{abstract}

Keywords: simplicity, income tax, final withholding tax.

\section{Intisari}

Pajak Penghasilan (selanjutnya, PPh) Final menghendaki objek PPh tertentu dipungut pajaknya berdasarkan penghitungan yang berbeda dengan penghitungan PPh umum, sehingga tidak dihitung menurut kemampuan membayar dari Wajib Pajak tersebut. Salah satu konsep yang dapat menjustifikasi penyimpangan tersebut adalah kesederhanaan dalam pemungutan pajak. Namun demikian, konsep ini tidak memiliki pemaknaan yang jelas dalam pemungutan PPh Final di Indonesia. Hasil penelitian menunjukkan bahwa secara konseptual terdapat beberapa pemaknaan konsep kesederhanaan yang dapat digunakan dalam memahami rezim PPh Final di Indonesia. Namun demikian, makna konsep kesederhanaan ini menyimpang dari konsep Pay As You Earn, yang mendasari rezim PPh Pemotongan, termasuk yang bersifat final.

Kata Kunci: kesederhanaan, $\mathrm{PPh}, \mathrm{PPh}$ final.

\section{Pokok Muatan}

A. Introduction 547

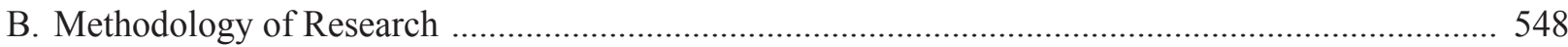

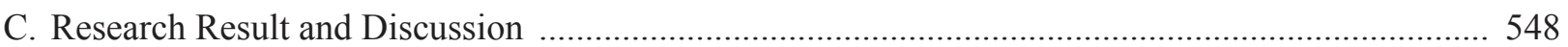

1. The Interpretation of Simplicity Concept in Final Income Taxation in Indonesia ..................... 548

2. The Interpretation of Simplicity Concept in Final Income Taxation Based on the Best Practice

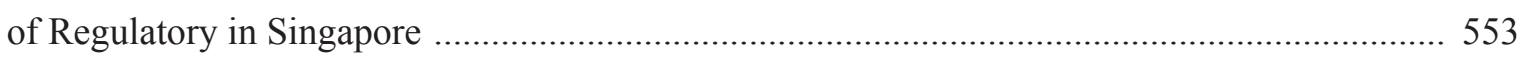

3. Recommendation of Final Income Tax Regulatory in Indonesia ............................................. 555

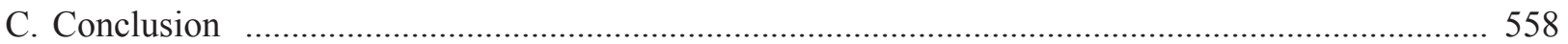

Research Results of Research and Community Service Department Faculty of Law Universitas Gadjah Mada 2014

Correspondence address: adrianto.dwi@mail.ugm.ac.id 


\section{A. Introduction}

According to proportion that a tax is a consequence of social life, thus, the increasing number of citizen has caused the increasing number of tax that has been received by State, as the tax controller and tax collector. However, the increasing number of society has affected the increasing of social economic activity, either qualitatively or quantitatively, thus, the government has a new potential which occurs from the commercial transaction which characterized the economic activity.

The higher of receiving tax which has been targeted to government through years it was predicted to empower for collecting the tax with the expense that is as low as possible for the revenue that is as high as possible. A motivation that is prima facie is valid. Yet, in its development, the main efficiency in taxation cannot be in line with the fulfilment of the rights of taxpayers (hereinafter TP) and the realization of justice between the TPs. For example is that the regulation regarding the examination of the applicable current tax, there is a possibility to prioritize the examination towards TP with certain categories, and ignore the examination towards the other TPs categories. Another example is within a regulation concerning the Income Taxation (hereinafter IT) as set forth in Government Regulation Number 46 of 2013 regarding the Income Tax on Income from the Accepted or Acquired by Taxpayer who Has Particular Gross Turnover, which has been proven contradicting with the justice principle and economic principle from taxation, ${ }^{1}$ there is a possibility that TP who suffers a loss remains to pay the Income Tax. ${ }^{2}$

The Income Taxation is included the Final Income Taxation as laid down in Article 4(2) Act Number 7 of 1983 regarding the Income Tax as amended with Act Number 36 of 2008 (hereinafter
Income Tax Act). The Final Income Tax regime has existed since the tax reformation occurred, the object was the income of interest and time deposits. ${ }^{3}$ However, there was the fourth amendment of Income Tax Act regime explicitly called as Income Tax Final, with the total income objects which are regulated become four types of income and other certain incomes, including that has been set forth in Government Regulation Number 46 of 2013 regarding the Income Tax on Income from the Accepted or Acquired by Taxpayer who Has Particular Gross Turnover.

The Final Income Tax has different characteristics with the Income Tax in general as stipulated in Income Tax Act. The main characteristic is that a turning point of The Final Income Taxation is on the object, that are the incomes coming from certain transaction. This characteristic of course contradicts with the main characteristic of Income Tax as a tax that has a turning point of taxation to its subject. Moreover, the income that becomes the object of Final Income Tax is the same with the income which becomes the object of general Income Tax. The income such as interest, business profits, and any advantages due to capital gain constitutes an income that is an object of general Income Tax and final Income Tax. Yet, the underlying transaction becomes the determinants on whether such income would be counted using the requirements laid down in Income Tax Act or the requirements set forth in Government Regulation regarding the Final Income Taxation towards particular income.

Furthermore, since the Final Income Tax focuses on the condition of its object and is intended for being differently governed with the provision stipulated in Income Tax Act, so that the proportion of Final Income Tax waived the ability to pay from $\mathrm{TP}$ is a logic consequence. The common reason is to justify the Final Income Taxation is the simplicity

Irine Handika, 2014, Rasionalisasi Pemungutan Pajak Penghasilan Final terhadap Usaha Mikro, Kecil dan Menengah, Research Report, Faculty of Law Universitas Gadjah Mada, Yogyakarta, p. 59.

See the Article 8 point (b) and (c) on Government Regulation Number 46 of 2013 the Income Tax on Income from the Accepted or Acquired by Taxpayer who Has Particular Gross Turnover.

See Article 4 point (2) Act Number 7 of 1983 regarding the Income Tax (State Gazette of Republic of Indonesia of 1983 Number 50 , Supplement to State Gazette of Republic Indonesia Number 3263). 
in taxation. This matter set forth in the elucidation Article 4(2) of Income Tax Act in which one the consideration in regulating the Final Income Tax is the simplicity in taxation. From the aforementioned, thus, the researcher intended to conduct a research regarding the implementation of simplicity in Final Income Taxation. The simplicity in Final Income Taxation tends to be constituted as an ease in conducting the calculation tax by TP on certain transactions, and as an ease in obtaining tax revenue by tax officials. Further, certain transaction that is chosen as the object of Final Income Tax tended to not having a justification as the implementation of Final Income Tax in other countries such as Singapore who has cross-border transaction.

Before conducting research, the researcher submits some basic proportions. Firstly, Final Income Tax constitutes an antithesis of general Income Tax. This means that Final Income Tax constitutes objective tax, so that it has nothing to do with the ability of TP, it is reflected from the application of proportional tariff and gross income in its calculation. Secondly, the Final Income Tax should be imposed to passive income, since it is only towards the passive income that the removal of deductible expenses in calculating the net income is justified, considering that its total is too low or none or unknown. Thirdly, the Final Income Tax should not be applied in transaction that does not constitute as a cross-border transaction, since there is no timing factor and an ease factor in transaction that needs to be achieved in domestic transaction.

Based on the background that has been elaborated above, it can be formulated that the issues in this research as follows: Firstly, how the interpretation of simplicity concept in Final Income Taxation in Indonesia? Secondly, how should the interpretation of simplicity concept in Final Income Taxation based on the best practice of the management of Final Income Tax in Singapore?
Thirdly, that are the recommendations that can be provided in refining the Final Income Tax regime in Indonesia?

\section{B. Research Method}

Theresearch concerning "The Implementation of Simplicity Concept in Final Income Taxation Regime in Indonesia" is a normative legal research. According to Istanto, ${ }^{4}$ a legal research is a research helped the development of legal science in revealing the truth of law. Besides, this research used comparative legal studies, that is a research conducted for understanding the similarities and differences of regulation that is applicable in every country or legal system, further there will be a unification of law of, vice versa, creation of law among legal systems. ${ }^{5}$

\section{Research Result and Discussion \\ 1. The Interpretation of Simplicity Concept in Final Income Taxation in Indonesia}

Based on Bahasa Indonesia Dictionary, the "sederhana" (simple) means not having so many details (difficulties and so on); not so many accessories; clear, whereas the word "kesederhanaan" (simplicity) means a thing (a condition, adjective) simple. $^{6}$ Such definition refers to a condition in which a subject or certain object that does not require there is a subject who enjoys such simplicity. Meanwhile, in Tax Law, the simplicity can be said as a principle, yet, as a concept succeeded from the main principle of taxation, that is the convenience of payment and economy of collection which has been postulated by Adam Smith and became two canons from the four canons of taxations. Adam Smith stated that "Every tax ought to be levied at the time of in the manner in which it is most likely to be convenient for the contributor to pay it". ${ }^{7}$ Whereas, Adam Smith defined economy of collection as "Every tax

F. Sugeng Istanto, 2007, Penelitian Hukum, Ganda, Yogyakarta, p. 29.

Ibid., p. 130

Language Center of National Education Department, "KBBI dalam Jaringan”, http://bahasa.kemdiknas.go.id/kbbi/index.php, accessed on 11 April 2014.

Citation from Adam Smith concerning canon of convenience in NN, "Economics Concepts, Canons/Principles of Taxation by Adam Smith", http://economicsconcepts.com/canons_of_taxation.htm, accessed on 11 December 2011. 
is to ne so contrived as both to take out and keep out of the pockets of the people as little as possible over and above what it brings into public treasury of the state". ${ }^{8}$ Some scientist, then postulated some approaches which can explain the definition and the standing of simplicity concept in taxation. Gordon ${ }^{9}$ put forward that there is an equality treatment among the TP who can reduce the potential tax avoidance. Meanwhile, IBFD ${ }^{10}$ thought that is a possibility of disobedience against the similarity principle in taxation, if the fulfillment of its principle cannot be achieved.

The author tried to answer the first research question by way of elaborating the method of Pay As You Earn (PAYE). The method of PAYE put forward the simplicity in income taxation towards the employees salary by way of withholding the tax when the income is received. In Indonesia, this concept was applied in Income Taxation Article 21. For tax officials, PAYE can alleviate the administrative burden for the tax examiner towards a tax report obligation (in Indonesia, the obligation of taxpayer for fulfilling the Annual Notification Letter, particularly due to the total of Annual Notification Letter that has to be checked can be substantially reduced and the assessment object can be focused on whether all the salary payment has passed through the tax withholding process by the employers, and whether the total that has been computed by the employers is already correct. ${ }^{11}$ For the employers, this method does not give any new administrative burden, since without any withholding tax, the employers has an obligation to conduct the other withholdings, such as pension contributions. Moreover, the employers can gain the financial advantage such as interest provide from the total tax which is already withheld by themselves and it is obliged to be distributed after certain period of time. ${ }^{12}$ The last but not least, for the employees, this method is beneficial as well since for those who has income up until certain amount can be released from the obligation to report. ${ }^{13}$ From the tax revenue pint of view, in some countries, this method ensures that $70 \%$ of state revenue from the individual income tax. ${ }^{14}$

From the aforementioned, it seems that the PAYE method realize the simplicity concept in taxation perfectly. Besides, the simplicity is defined as a concept that is measured and evident its advantage for all parties in taxation, that are tax officials, taxpayers, and tax withholders. For tax officials, such advantage has to be manifestly giving contributions in the fulfillment of budgetary function such as the certainty of incoming tax into state treasury within years, and regulatory function for tax such as the decreasing expenses of obedience as a result of narrowing of an object supervision. For taxpayers, such advantage is its reduction of liability to pay the tax, primarily an obligation to report, even though for certain types of taxpayers need to be adjusted. At last, for the tax cutters, such advantage can be no any additional administration burden with regards to the implementation of corporate financial accounting system, and in certain regime such advantage can be a financial advantage such as interest from the tax deducted and withheld for certain period of time. Based on literature studies conducted by the author, the concept of simplicity in taxation on Final Income Tax in Indonesia firstly introduced in 2000 through the enactment of Government Regulation Number 132 of 20000 regarding the Income Tax towards raffle prizes. In such regulation, the simplicity concept is defined as "a convenience of individual or entity in fulfilling its tax liability". This matter can be explained from paragraph 2 of general elucidation:

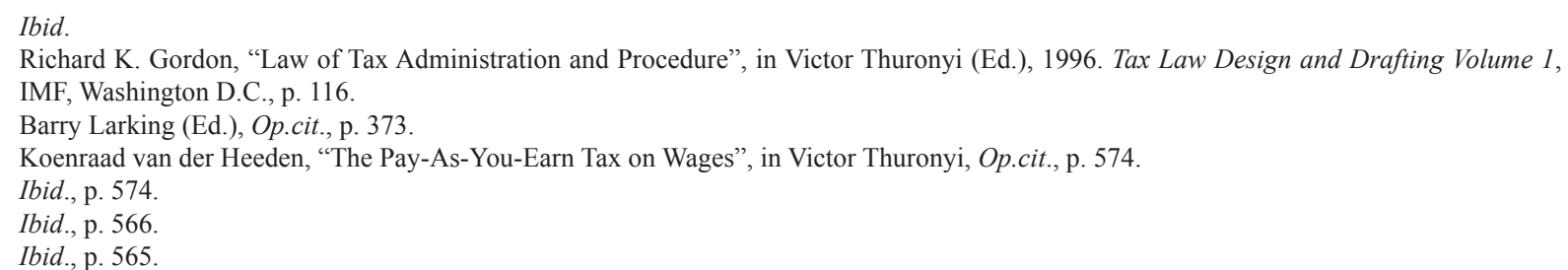


For providing the convenience and legal certainty as well as raising an obedience of individual or entity in accomplishing its tax liability, and in compliance with the provision in article 4 (2) Act Number 7 of 1983 regarding Income Tax as amended with the Act number 17 of 2000, the imposing of Income tax on raffle prizes needs to be governed separately with a Government Regulation.

The same elucidation can be found on Government Regulation Number 51 of 2008 regarding Income Tax towards Income of Construction Service Business as amended with the Government Regulation Number 40 of 2009; Government Regulation Number 15 of 2009 regarding the Income Tax on Saving Interest Paid by the Cooperation to Individual Cooperation Members; Government Regulation Number 16 of 2009 regarding Income Tax on Obligation Interest Income; and Government Regulation Number 46 of 2013 regarding Income Tax on Income of the Accepted or Acquired by Taxpayer who Has Particular Gross Turnover.

The interpretation of simplicity concept in Final Income Taxation can be conducted by way of comparing among the regulation of Final Income types. Based on the research conducted by the author, up until 2013, there are 12 types of Final Income Tax governed by Article 4(2) Income Tax Act. The criteria used by the Act is the types of tax subject set forth as taxpayers; income as object of Income Tax; when the tax debt; the amount of the tariff that is used; taxation system that is used for tax debt payment; tax report mechanism; and the availability of an option for taxpayers. Some of Final Income Tax features that can be concluded the comparative legal research provide the explanation with regards to the interpretation of simplicity concept in Final Income Taxation in Indonesia as follows:

a) Subject of Income Tax can be an individual or a domestic entity; one of the feature that is found in Final Income Tax regime is that the subject of tax imposed by Final Income Tax can be an individual or a domestic entity. This requirement can be found in all types of Final Income Tax. If it is related to Potput Income Tax in which the deduction is final which is only imposed to Article 26 Income Tax that governs the Income Tax deduction on Income Paid by taxpayers in domestic level, including Permanent Establishment (Bentuk Usaha Tetap) in Indonesia, to the taxpayers in foreign country, so that Final Income Taxation can be said inconsistent with Potput Income Tax regime. The main reason is the nature of final from the deduction of Income Tax article 26 is due to taxpayers in foreign country does not have any obligation to report in the form of Annual Notification Letter, as laid down in Article 2(2) of Income Tax Act. Moreover, Burns ${ }^{15}$ makes this character as a main character in the definition of Final Income Tax, by way of declaring that: "Final withholding taxes on gross income are the usual method for assessing nonresidents on income from capital. A final withholding tax means the recipient is not required to file a return or face additional assessment in the source jurisdiction with respect to income subject to the tax". With regards to this matter, the domestic taxpayers have an obligation of such reporting, so that the application of final nature in Income Tax deduction in domestic transaction is inappropriate. In addition, Indonesia recognizes the calculation system of global income, in which a taxpayer adds all of the income which is the object of Income Tax as stipulated in Article 4 (1) Income Tax Act, either coming from Indonesia or outside Indonesia, and it deducts the expenses as set forth in Article 6 (1) and (2), Article 7 (1) regarding Non Taxable Income, and Article 9 (1) points c, $\mathrm{d}$, e, and $\mathrm{g}$ of Income Tax Act. Such

15 Lee Burns and Richard Krever, "Taxation of Income from Business and Investment", in Victor Thuronyi (Ed.), Op.cit.,p. 671. 
calculation is set forth in Article 16 (1) of Income Tax. Therefore, the author thinks that the Final Income Taxation does not need to be applied in transaction in which the income recipient is domestic taxpayers.

b) An Income imposed by Final Income Tax can be an active income, such as business profits or income related to delivery service; and passive income, such as interest, dividend, and loan; as well as income from capital gain; based on the comparative legal research, it can be concluded that from 12 Final Income Tax Regime, there are 2 types of Final Income Tax in which can be imposed by business income of other active income, 6 types of Final Income Tax imposed by the passive income, and 4 types of Final Income Tax imposed by capital gain income. The problem raised in this character is that the Income Tax regime which uses gross income as the basis of taxable income calculation is proper in case it is applied to passive income, such as interest, dividend, and loan. This concept is stated by Burns ${ }^{16}$ saying that: "Withholding on income derived by self-employed persons who are resident taxpayers will generally not be a final tax. A taxpayer will be required to file a return showing taxable income for the tax year tax payable thereof, and a tax offset will be given for the withholding tax". One of the reason why Income Tax can only be properly imposed to passive income is that the amount of expense can be assumed to the passive income which is relatively low or even there is no expense, thus, the exemption of expenses deduction can be justified. For instance, the expenses that can be allocated to the income could be the lowest saving interest, thus, the Final Income Tax that imposed to this type of income still reflects the ability to pay from the taxpayer. In the other way around, the expenses that can be allocated to income such as business profits cover many elements of expenses, yet, it is not limited to expense for purchasing materials, the expenses related to occupation or service, trip expenses, waste management expenses, and administrative cost, as stipulated in Article 6 (1) Income Tax Act. Therefore, the regulation of gross income calculation as set forth in Government Regulation Number 51 of 2008 regarding the Income Tax on Construction Service Business Income as amended with the Government Regulation number 40 of 2009 and Government Regulation Number 46 of 2013 regarding the Income Tax on Income of the Accepted or Acquired by Taxpayer who Has Particular Gross Turnover is inappropriate. This would be the same with the income that is due to capital gain. Article 4 (1) point $\mathrm{d}$ Income Tax Act regulates that can be an object of Income Tax Act is a profit obtained from subject of tax due to the purchase of wealth with the higher price from the left value or higher than the price or acquisition value. Meanwhile, Article 4 (2) Government Regulation Number 48 of 1994 regarding the Income Tax on Income of the Transfer of Land Rights and/or Building as amended with the Government Regulation Number 71 of 2008 which governs that the basis of taxation that is applicable in calculating Income Tax that is payable on the transfer of land rights is a value of transfer of right as implied in section (1) is the highest value between the value based on Transfer of Right Deed with the sale value of the object of land tax and or its building as lied down in regulations which governs regarding the Land and Building Tax on Rural and Urban Areas. Thus, the concept of simplicity in Final Income Taxation has deviated from the definition of Income based on Income Tax Act. The Final Income Tax governed in such Act is not more that tax on land rights transfer and/or building, which 
resemble Custom Revenue of Land Rights and or Building.

c) The tax payers do not have any option for calculating payable Income Tax based on net income; based on comparative legal research can be known that most of the incomes which has been imposed by Final Income Tax subjected by gross income, without any option for the taxpayers for calculating the net income. There is only type of income subjected to Final Income Tax that is possible for the taxpayers to calculate the net income, namely the additional income from transaction stock sale as stipulated in Government Regulation Number 41 of 1994 regarding the Income Tax in Income from the Sale of Stock Transaction in a Stock Exchange as amended with the Government Regulation Number 14 of 1997. As it was discussed from the point before, such concept is reasonable for being imposed to passive income, however, it would not be reasonable for being imposed to active income and profits due to capital gain. Such requirements are indeed simple, since making he taxpayers easier for calculating the taxable income. However, if there is a Norm of Net Income Calculation as regulated in Article 14 of Income Tax Act, so this concept will motivate the taxpayers for not having any bookkeeping or record as set forth in Article 28 of UUKP. This matter can be clearly seen on the General Elucidation of Government Regulation Number 46 of 2013 regarding the Income Tax on Income from the Accepted or Acquired by Taxpayer who Has Particular Gross Turnover, which stated the way of payable Income Tax Calculation found in such regulation based on the policy for simplifying the taxation, reducing the administrative burden of taxpayers and tax officials, and it aims to provide the convenient for taxpayers in certain group, that is for those who do not have any bookkeeping and are only able to identify the gross income.

d) The Calculation of Payable Final Income Tax using Proportional Tariff; further, the concept of simplicity in taxation of Final Income tax is manifested by way of determining proportional tariff. The amount of tariff may vary, starting from $0.1 \%$ until $20 \%$. Conceptually, the determination of proportional tariff can simplify the calculation of payable Income Tax, only if the taxpayers are able to identify the amount of tariff imposed by the received income. According to the Author, this matter can only be manifested if the proportional tariff has a nature of single. For instance, towards the taxpayers, the amount of tariff that is imposed by the received income is single, it is $25 \%$ as stipulated in Article 17(1) point b juncto point (2a) of Income Tax. However, based on the table above, there are only four incomes which are subjected to Final Income Tax that has single tariff. Another eight types of income only have a structure of different proportional tariff for every subject of tax and/or object of the tax. As a consequence, the taxpayers has to pass through process of understanding the requirements of regulations in detail in order to get to know the applicable tariff in transaction that is conducted by them. This matter it is of course in accordance with the word 'simple' as what has already been discussed in the beginning of this chapter, that is "not so many detail (difficulties and so on); not so many accessories". Hence, it can be concluded that some Final Income Tax can be paid by way of the taxpayers calculating and paying the payable tax.

e) The Final Income Tax can be deducted by the party who pays the income, or paid by the taxpayers who received the income; based on the table, it can be concluded that some Income Tax is paid by way of the taxpayers calculating and paying their own taxable income. Income Tax is paid by the income received from the land rights and/or building transfer, the additional income from the transaction of founder transfer of share, the income from land or building leasing paid by 
non-tax withholders, the income of Construction Service Business paid by non-tax withholders, and income of the Accepted or Acquired by Taxpayer who Has Particular Gross Turnover obliges the taxpayers to calculate, pay and report the taxable Final Income Tax to them. This is inconsistent with the concept of simplicity in taxation, as discussed before.

\section{The Interpretation of Simplicity Concept in Final Income Taxation Based on the Best Practice of Regulatory in Singapore}

The criteria that is used in analyzing the regulatory of Final Income Tax applicable in Singapore is the same with the criteria that is used in analyzing the Final Income Tax regulatory in Indonesia, that is the type of tax subject which is known as taxpayers; the use of the amount of tariff; the system of taxation that is used in the payment of taxable tax; mechanism of tax report; and the availability of options for taxpayers. Based on the comparative legal studies, some of the features of Final Income Tax that can be concluded from the table above and providing the explanation regarding the interpretation of simplicity concept in Final Income Taxation in Singapore as follows:

a) Subject of Final Income Tax is individual and foreign entity; from the regulation as set forth in the table above, it can be said that Final Income Tax in Singapore can only be imposed towards persons who are subject to foreign tax. This kind of requirement is good, because the treatment towards the subject of tax in domestic level and international level is different in principal. In European Union, the judges of European Court of Justice examined Case Number 279/93 on 14 February 1995 between the Finanzamt Köln-Altstadt v. Roland Schumacker ${ }^{17}$ held that: "a non-resident's personal ability to pay tax, determined by reference to his aggregate income and his personal and family circumstances, is more easy to assess at the place where his personal and financial interests are centered. In general, that is the place where he has his usual abode. Moreover, that State generally has available all the information needed to assess the taxpayer's overall ability to pay, taking account of his personal and family circumstances". Based on such precedent, it can be concluded that the realization of the ability principle to pay becomes the obligation of the domicile countries (resident countries), and not the country of origin. The allocation of rights of domicile country taxation towards the subject of tax in their country is related to the jurisdiction in which the subject of tax obtains from most of the income. Besides, the information that can be obtained from the domicile countries towards the subject of tax is relatively limited. Those two reasons is reasonable enough for prohibiting the domicile countries to simplify the calculation of taxable income for any reason. It is therefore, the domicile countries is prohibited for collecting the Income Tax towards the subject of tax in their country against the income calculated by way of gross income and non-progressive tariff, whereas the country of origin can do this for the purpose of simplicity in taxation.

b) The income subjected to Final Income Tax is active income from profession, and passive income such as interest, dividend, and loan; based on the table above, it can be said the income subjected to Final Income Tax in Singapore covered the active and passive income. The active income subjected to Final Income Tax is the income coming from the profession activity and vocational conducted by individual and entity which is not domiciled in Singapore, unless the income received from arbitrators and public entertainer. However, it is different from the Final Income Tax subjected to active income in Indonesia, individual or entity that is 
imposed such Final Income Tax can choose for being calculated the net income (chargeable income) with the deductions as regulated in Section 40 SITA, that regulates Relief for nonresident citizens and certain other non-residents. It needs to be known that Chargeable Income in Singapore is "the remainder of his assessable income for that year after the reliefs and deductions allowed in this Part have been made," as stipulated in Section 38 SITA. Hence, the simplicity is define as a policy that provides an option for the foreign taxpayers for calculating its net income or gross income, so that it remains focusing on the ability to pay from the taxpayers. However, the requirements regarding the tax reporting become the authorization of tax officials. It means that tax officials are able to, by way of notification, determine for those who need to submit the letter of notification (returns), and release certain persons from such obligations. Section 62 SITA does not explain further concerning the criteria used for determining or releasing such obligations. Thus, the simplicity can be interpreted as a policy which provides a discretion for tax officials in determining persons, either in domestic or abroad, that needs to be assessed the obedience by way of the obligation of reporting.

c) The Calculation of Payable Final Income Tax using Proportional Tariff and in the Nature of Single; like the regime of Final Income Tax in Indonesia, the Final Income Tax in Singapore is also subjected with progressive tariff. The difference is the structure of its tariff does not have any complexity as it is found in some types of Final Income Tax in Indonesia. A type of Income tax subjected to single tariff, thus, the taxpayers only need to identify the type of its income and can directly calculate the payable Income Tax by way of multiplying the applicable single tariff. The single tariff is effectively still equal with the applicable tariff if the recipients are the domestic taxpayers in Singapore, thus it does not violate the principle of nondiscrimination in International Tax Law. As a comparison, in European Union, European Court of Justice held precedent with regards to tariff which is allowed for the country of origin in calculating the Income Tax to a foreign taxpayer and it is calculated from gross income (without any expenses deduction), that is: ${ }^{18}$ "[....] those articles of the Treaty [EC Treaty - red.] do not preclude that same provision in so far as, as a general rule, it subjects the income of non-residents to a definitive tax at the uniform rate [....] deducted at source, whilst the income of residents is taxed according to a progressive table including a tax-free allowance, provided that the rate [....] is not higher than that which would actually be applied to the person concerned, in accordance with the progressive table, in respect of net income increased by an amount corresponding to the tax-free allowance". Based on such precedent, it can be concluded that foreign tax payer can be subjected to Income Tax of gross income, which its amount is more than Income Tax of net income after being deducted by the non-taxable income from domestic taxpayer. As long as the total of payable Income Tax of Gross income is still under such limit, thus, in principle, the country of origin has a freedom in determining the Final Income Tax tariff. From the simplicity aspect in calculating the Income Tax, the author has declared before that the single tariff supports the simplicity for the taxpayers in calculating the payable Income Tax.

d) Final Income Tax is deducted by the party who pays the income; the data in the table shows that the authority for burdening the obligation of tax

18 European Court of Justice, Case C-234/01, 12 June 2003, Preliminary Ruling on case Arnoud Gerritse v. Finanzamt Neukölln-Nord, Paragraph 55 . 
reporting towards the taxpayers is considered as the full authorization of tax officials. However, Section 45 (1) SITA governs that: "Where a person is liable to pay to another person not known to him to be resident in Singapore any interest which is chargeable to tax under this Act, the person paying the interest shall - a. deduct therefrom tax $-[\ldots]$ (iii) where Section $43(3)$ or (3A) is applicable to the person to be paid, at the rate specified in that provision, on every dollar of the interest; and immediately give notice of the deduction of tax in writing and pay to the Comptroller the amount so deducted, and every such amount deducted shall be a debt due from him to the Government and shall be recoverable in the manner provided by Section 89". Based on such requirements can be concluded that the imposing of Final Income Tax in Singapore is only conducted by way of withholding tax performed by the parties who pay the income that constitutes domestic Tax Payer in Singapore. The income recipient, that is the foreign taxpayer, does not have any obligation to pay tax directly to Singapore authority tax. Moreover, the payable Income Tax that occurs from such transaction becomes the debt of Income Tax that can be charged from depositor income, as governed in Section 45(3) SITA, as follows: "Where a person fails to make a deduction of tax which he is required to make under subsection (1), any amount which he fails to deduct shall be a debt due from him to the Government and shall be recoverable as such". This requirement shows that the position of a country towards the domestic taxpayer who is the depositor income and Income Tax withholder. A state has an authority to determine the obligation of withholding tax for taxpayers in their country. As explained before, the concept of tax withholding realizes the simplicity in taxation of Income Tax. Conversely, the system of taxation on self-assessment does not support the simplicity in taxation of Income Tax, because the income recipient remains bearing the economical burden and administrative simultaneously.

\section{Recommendation of Final Income Tax Regulatory in Indonesia}

Recommendation from the author aims to restore the concept of the taxation of Income Tax, thus in accordance with the classic principles of taxation. Before, the author would like to call back the definition of simplicity in taxation on Final Income tax regime in Indonesia as analyzed and discussed in the previous chapters. According to the author, the regime of Final Income Tax is inconsistent with the concept of simplicity that is declared by the scholars, mainly because:

(1) all of the Final Income Tax is collected for domestic transaction, and (2) some types of Final Income Tax collected: (a) towards the active income; (b) calculated by using gross income without any option for taxpayer in calculating with net income; (c) with different proportional tariff for a type of Final Income Tax; and (d) using the system of self-assessment tax collection. Besides, the Final Income Tax regime which is applicable at moment has deviated from the concept of simplicity as postulated by Bawazier ${ }^{19}$ when the beginning of regime was introduced, as follows: "The increasing of efficiency in taxation can be achieved by way of spreading out the system of collecting and withholding of tax[...], particularly towards the economic activities that are relatively difficult in taxation, by holding the simplicity principle in order to the taxation can be conducted fast, cheap, easy and practical, thus the expansion of such taxation and withholding system does not hamper the development of economic activity as such". According to those reasons, it can be identified and analyzed that some characters that should exist in

19 Fuad Bawazier and M. Ali Kadir, “Kebijakan dalam Tax Reform 1994 dan Tax Reform 1997”, in Anggito Abimanyu and Andie Megantara (Eds.), 2009, Era Baru Kebijakan Fiskal: Pemikiran, Konsep dan Implementasi, Kompas Publisher, Jakarta, p. 155. 
interpreting the simplicity in collecting the Final Income Tax, are: Firstly, Final Income Tax is only subjected to income that is received by foreign tax subject or that is relatively difficult of its taxation. As already discussed before, the taxation of Final Income Tax towards the foreign tax subject based on the difficulties for burdening the obligation of reporting to such subject of tax, unless if the subject of tax has BUT in Indonesia, in which the obligation of its reporting, including the obligation to conduct the bookkeeping that underlies the making of Annual Notification Letter and/or ANL for a certain period, it is made the same with the obligation to report for the other subject of domestic entity tax. Conversely, the taxation of Final Income
Tax towards the domestic subject of tax cannot be justified, because as discussed before, the domicile country has the authority towards persons who domiciles in its region, including for burdening the obligation to report and payment of tax with the method of self-assessment. Excluding for this matter can be given towards the economic activities that is relatively difficult in its taxation, as cited from Bawazier before. However, there is a need of clear definition and measured towards the economic activity that is "difficult in its taxation". One of the measurement that can be used is the amount of the paid income. For instance, the payment of interest and deposit, as follows: ${ }^{20}$

Table 1. Burden of Saving Interest and General Deposit the Period of October 2013March 2014 (in billion Rupiah)

\begin{tabular}{lcccccc}
\hline \multirow{2}{*}{$\begin{array}{l}\text { Type of Bank } \\
\text { Products }\end{array}$} & October & November & December & January & February & March \\
& $\mathbf{2 0 1 3}$ & $\mathbf{2 0 1 3}$ & $\mathbf{2 0 1 3}$ & $\mathbf{2 0 1 4}$ & $\mathbf{2 0 1 4}$ & $\mathbf{2 0 1 4}$ \\
\hline Saving & 15.829 & 17.457 & 19.231 & 1.730 & 3.326 & 5.042 \\
\hline Deposit & 67.224 & 75.661 & 84.903 & 9.608 & 18.653 & 28.947 \\
\hline
\end{tabular}

Source: Financial Service Authority of Republic of Indonesia, 2014.

Based on the table, it can be said that the payment of saving interest and deposit, that becomes one of the income subjected to Final Income Tax, has a huge transaction scale, particularly in the last three months. It needs to be noted that such data does not cover the interest income for other types of bank, such as limited bank, credit bank and sharia bank. Such data does not cover yet the total of customers of bank located in Indonesia. However, the amount of value that become the imposed tax which is up to billions rupiah in a month, is enough to justify that the imposing Income Tax based on the types of income of saving interest and deposit that is paid by bank including as the type of income coming from economic activity that is difficult in its taxation. Another measure that can be used is volume and transaction frequency, such as volume and frequency of stokes sale, as follows:
Table 2. The Recapitulation of Volume and Shares Transaction Frequency in Indonesia Stock Exchange (Quarter IV of 2013 and Quarter I of 2014)

\begin{tabular}{|c|c|c|}
\hline \multirow{2}{*}{$\begin{array}{l}\text { Shares } \\
\text { Commercial } \\
\text { Indicator }\end{array}$} & \multicolumn{2}{|c|}{ Period } \\
\hline & $\begin{array}{l}\text { Quarter III } \\
\text { of } 2013\end{array}$ & $\begin{array}{c}\text { Quarter I of } \\
2014\end{array}$ \\
\hline $\begin{array}{l}\text { Volume } \\
\text { (million sheets of } \\
\text { shares) }\end{array}$ & 283.617 & 283.746 \\
\hline Frequency (times) & 7.595 .821 & 12.791 .427 \\
\hline
\end{tabular}

Sources: IDX Statistics 1 ${ }^{\text {st }}$ Quarter 2014.

Based on the data and information showed in the table, it can be drawn that shares commercial transaction involved volume of trading and total of huge frequency. Such data can be added more with the average of daily transaction volume that is up to 4.727 .000 sheets of shares and frequency as much as 126.597 times in quarter IV of 2013, and

20 Financial Service Authority of Republic of Indonesia, "Indonesian Banking Statistic”. Vol. 12, No. 4, March 2014 , p. 11. 
4.729.000 sheet of shares and frequency as much as 213.190 times in quarter I of 2014. If it is added by a condition that both income are paid to the foreign and domestic subject of tax, thus, the importance of Final Income Taxation is enough strong. This is true that such number is relative, and there are more transactions in other economic activity has the similar difficult level in its taxation. In this matter, the government needs to map the types of economic activities in which involved the volume and frequency as well as the transaction in a period, for later on to determine the minimum amount of such three aspects that has been fulfilled before determining certain income as the income subjected to Final Income Tax.

Secondly, Final Income Tax is better subjected to passive income, or to active income and capital gain with an option of calculation on taxable net income. In the sub chapter IV.A is already discussed regarding the reason of the necessity to limit the Final Income Tax collection towards the income coming from capital gain that is inappropriate with the concept of capital gain as one of the type of taxable income. Sub chapter IV.B has already discussed regarding the taxation on Final Income Tax towards the active income that remains giving the option for the taxpayers for calculating the net income. According to the author, the first thing that needs to be done is revitalization of income interpretation in Final Income Tax regime. An income must be interpreted as an additional economic function, and not the whole gross income that is received by the taxpayers. In the context of passive income, this means that the taxable income must be calculated by way of deducting the deductible expenses form the gross income. Meanwhile, in the context of an income from capital gain, this means the taxable income must be calculated from the difference between the market value and historical value. Second, as long as the type of income constitutes as an active income, thus the taxpayer has to be given an option for calculating its net income. This option has to be given for domestic taxpayer and can be given for foreign taxpayer. Tax general director has an authority to calculate back the taxable tax on domestic taxpayers by way of tax examination, so that the subjected Final Income Tax towards the active income is not urgent. This option can be regulated by way of the amendment of Government Regulation which regulates regarding the taxation of Final Income Tax. The other option, that needs to change towards the Income Tax Act, is by way of issuing the active income from the type of income that is subjected by the Final Income Tax, and move it in the withholding and taxation regime as regulated in the article 21,22 and 23 of Income Tax Act. The last option is by way of determining the active income subjected to Final Income Tax as the income subjected to Income Tax article 25, that is Income tax that is paid gradually by taxpayers for every tax period.

Thirdly, The Final Income Tax subjected using the single tariff. as what has been discussed in the chapter IV.A, proportional tariff subjected to the regime of Final Income tax in Indonesia uses many proportional tariff that is compound, so that the taxpayers remains to read the Act carefully in order to understand how much tariff should be paid. In this context, the Final Income taxation in the near future is better to use the single proportional tariff. the simplicity in calculating the Income Tax for the taxpayers can only be realized if the taxpayers easily notice how much tariff subjected to their income, without any complexity in identifying the tariff in accordance with its condition. In other words, there is no "complex steps" that should be passed by the taxpayers in calculating the taxable income tax.

Fourthly, Final Income Taxation can only be taxed by way of withholding or taxation. The taxation of Income Final Tax that is conducted without any withholding or taxation by third party in principle can be realized the simplicity in such regime. By way of withholding and taxation, as what has been stipulated in the concept of PAYE, it occurs that the obligation burden separation between the economic and administrative obligation. The economic burden remains on the hand of income recipient, as the executor from the tax concept attached on the 
Income tax. Conversely, the administrative burden such as withholding, deposit, and reporting shifted to tax withholders and tax collector. By way of this method can be realized in a simplicity in collecting the Final Income Tax in Indonesia. Besides, this method can make the supervision easier conducted by the tax officials, because a withholder or tax collector in general deduct or collect the tax for the tax payers. Therefore, the Final Income tax in near future is better to use a single method of taxation, that is withholding and taxation by third party, and not with the system of self-assessment.

\section{Conclusion}

Based in the aforementioned, and for answering the legal issues in this research can be concluded that: Firstly, the concept of simplicity in Final Income Tax in Indonesia interpreted as a regime of the collection of Income Tax which provide the government for a flexibility in determining the option of policy in executing the budgeter function and governs from tax. In the beginning of 1983, the government distinguished the implementation of Income Tax in enhancing the development of certain type of saving, in the 2013, the government distinguishes the implementation of Income Tax towards the taxpayers who have certain income in improving the tax obedience. The concept of simplicity in collecting tax is no longer based on the measures for providing justification on the violation of equality principle, so that there is shifting paradigm in interpreting the concept of simplicity in Final Income Tax in Indonesia. The Final Income Tax regime in Indonesia is inconsistent with the concept of simplicity that is declared by the scholars, due to: (1) all of the Final Income Tax is collected for the domestic transaction, and (2) some of the type of collected Final Income Tax: (a) for the active income; (b) calculated using the gross income without any option for the taxpayers in conducting the calculation by way of net income; (c) with the different proportional tariff for a type of Final Income Tax; and d) using the system of selfassessment tax.
Secondly, the concept of the simplicity in Final Income Tax in Singapore interpreted as a Final Income Tax regime which prioritize Pay As You Earn concept, by way of holding on to the principle of the ability to pay from the taxpayer. The Final Income Tax in Singapore can only be subjected towards the income recipient who are the foreign taxpayer, since Singapore as a country of origin, has a jurisdiction border towards such taxpayers, so that the simplicity is an option that has to be passed in the achievement of the effectiveness and efficiency of Final Income Tax. However, in the process of holding the principle of an ability to pay from the taxpayers, towards the foreign taxpayers subjected to Final Income Tax on active income obtained from the profession is given options, that cannot be revoked, for calculating the taxable Income Tax is the same with the applicable tax for the domestic taxpayers in Singapore, that is based on net income and with progressive tariff. As if such option has not been used, so the structure of Final Income Tax tariff in Singapore is relatively easy to be applied, due to its single nature without any complexity based on its income subject of object. At last, the Final Income Tax in Singapore is applied with the concept of PAYE, so that the income recipient does not need to calculate and pay the taxable Final Income Tax in Singapore.

Thirdly, the revolution of Final Income Tax regime in Indonesia is urgent. This is because of the applicable Final Income tax regime is not in accordance with the concept the early regime. The Final Income Tax subjected to the economic activity and the criteria as well as certain method, now it is imposed to the domestic economic activity in the purpose of tax intensification. The criteria and method that are used in Final Income taxation may vary, so that there is no consistency between the types of Final Income tax. Furthermore, the Income Tax Act makes the government become possible to determine the other type of income subjected to Final Income Tax. This condition must be anticipated by the government in order to re-organize the Final Income Tax in the future. Some recommendations 
towards the regulatory of Final Income Tax in the future is that the Final Income Tax shall be: (a) only subjected to the foreign tax subject; it is difficult to conduct the investigation and tax billing; (b) it is only subjected towards the passive income or can be subjected to the active income and capital gain however by way of giving an option for taxpayers in calculating the net income; (c) subjected to the single proportional tariff; and (d) collected by the method of withholding or collecting by the third party so there is no self-assessment.

\section{REFERENCES}

\section{A. Buku}

Abimanyu, Anggito and Andie Megantara (Eds.), 2009, Era Baru Kebijakan Fiskal: Pemikiran, Konsep dan Implementasi, Kompas Publisher, Jakarta.

Istanto, F. Sugeng, 2007. Penelitian Hukum, Ganda, Yogyakarta.

\section{B. Research Report}

Handika, Irine, 2014, Rasionalisasi Pemungutan Pajak Penghasilan Final terhadap Usaha Mikro, Kecil dan Menengah, Research Report, Faculty of Law Universitas Gadjah Mada, Yogyakarta.

\section{Antology}

Bawazier, Fuad and M. Ali Kadir, "Kebijakan dalam Tax Reform 1994 dan Tax Reform 1997”, in in Anggito Abimanyu and Andie Megantara (Eds.), 2009, Era Baru Kebijakan Fiskal: Pemikiran, Konsep dan Implementasi, Kompas Publisher, Jakarta.

Gordon, Richard K., "Law of Tax Administration and Procedure", in Victor Thuronyi (Ed.), 1996, Tax Law Design and Drafting Volume 1, IMF, Washington D.C.

\section{Regulation}

Act Number 7 of 1983 regarding the Income Tax (State Gazette of Republic of Indonesia of 1983 Number 50, Supplement to State Gazette of Republic Indonesia Number 3263).

Government Regulation Number 46 of 2013 regarding the Income Tax on Income from the Accepted or Acquired by Taxpayer who Has Particular Gross Turnover.

\section{E. Internet Source}

Economics Concepts, "Canons/Principles of Taxation by Adam Smith", http://economicsconcepts.com/canons_of_taxation.htm, accessed on 11 Desember 2011.

Language Center of National Education Department, "KBBI dalam Jaringan", http:// bahasa.kemdiknas.go.id/kbbi/index.php, accesed on 11 April 2014.

\section{F. Verdict}

European Court of Justice, Case C-234/01, 12 June 2003, Preliminary Ruling on case Arnoud Gerritse v. Finanzamt Neukölln-Nord. 